\title{
Fauna of Sandy Beaches in Bachok, Kelantan
}

\author{
Sasekumar A.*, H. H. Moh and S.H. Muhammad Ali ${ }^{1}$ \\ Institute of Biological Sciences, Faculty of Science, University of Malaya, 50603 Kuala Lumpur \\ ${ }^{1}$ Borneo Research Institute, Universiti Malaysia Sabah, Kota Kinabalu, Sabah 88999, Malaysia. \\ *sasekumarga@live.com.my (Corresponding author) \\ Received on $2^{\text {nd }}$ July 2009, accepted in revised form $7^{\text {th }}$ December 2009.
}

\begin{abstract}
The fauna of two sandy beaches on the Bachok coast of Kelantan were studied during June 2008. Sand was dug up to a depth of $30 \mathrm{~cm}$ with a spade, and washed in a sieve of $2 \mathrm{~mm}$-mesh size at the water's edge to collect the fauna. Fifteen species of invertebrates consisting of gastropods, bivalves, crustaceans and an echinoderm were recorded. The most common were ghost crab Ocypode ceratophthalma, sand bubble crab Scopimera proxima, hermit crab Diogenes avarus, bivalve Meretrix sp. and sand dollar Arachnoides placenta. The moist sand in the lower part of the shore supported a higher diversity of fauna than the dry sand of the upper shore.
\end{abstract}

\begin{abstract}
ABSTRAK Kajian telah dijalankan terhadap fauna yang hidup di dua pantai berpasir di Bachok, Kelantan pada Jun 2008. Pasir telah dikorek sampai sedalam $30 \mathrm{~cm}$ dengan penggali dan kemudian dibilas dalam penapis yang mempunyai saiz 'mesh' $2 \mathrm{~mm}$ di tepi pantai. Lima belas spesies invertebrata dari kumpulan gastopoda, bivalvia, krustacea dan echinoderm telah dijumpai. Invertebrata yang biasa dijumpai ialah ketam hantu, Ocypode certaophthalma, ketam gelembung, Scopimera proxima, kepah Meretrix dan "sand dollar", Arachnoides placenta. Kawasan pantai bawah yang berpasir basah menyokong diversiti yang lebih tinggi daripada kawasan pasir kering di pantai atas.
\end{abstract}

(Keywords: sandy shore, fauna, Ocypode ceratophthalma, Diogenes avarus, Arachnoides placenta)

\section{INTRODUCTION}

The coastal plains of Kelantan consist of a belt of alluvium averaging $8 \mathrm{~km}$ width with occasional isolated hills. The beaches are largely built of coarse quartz derived from weathered granite. The sand surface of the beach ridges or "permatang" allows only for a savannah-like vegetation of open bushes and lallang [1]. The agricultural value of these sands, on which acidic podosolic soils develop, is low and only coconut palms can be cultivated. The grass cover prevents sand grains from being blown away by wind.

Along relatively stable sandy shores such as Bachok, the vegetation is pes caprae association, a low herbaceous plant cover over a broad sand strand, of which most members are creeping plants with long, rooting stolons or stems [2]. Typical species include Spinifex littoreus, Ipomoea gracilis and I. pres caprae. Seedlings of beach trees, including coconuts from water-borne fruits and wind-dispersed Casuarina equisetifolia may form pure stands on beach ridges.

The fauna of sandy breaches on the east coast of Peninsular Malaysia has not been investigated with the exception of a brief study by Leong [3] as part of a general survey of the coastal marine resources and general observations of shore types [4].

\section{METHODS OF STUDY}

Two sand beaches were sampled, one at the beach fronting the Sudara Beach Resort (SBR) on $15^{\text {th }}$ June 2008 at $10.30 \mathrm{pm}$, and the other at Kuala Rekang beach, the location of the proposed IOES (Institute of Ocean and Earth Science) station. The latter location was sampled on $17^{\text {th }}$ June 2008 at $4.00 \mathrm{pm}$. On the both locations, the beach was sampled from the upper shore at 20 to 30 metre intervals until the water's edge low down the shore (Table 1). Sand from a quadrat area of approximately $30 \mathrm{~cm} \times 30 \mathrm{~cm}$ was dug up to $30 \mathrm{~cm}$ depth and placed on a $2 \mathrm{~mm}$ mesh sieve and then washed at the water's edge. The macrofauna remaining on the sieve were collected and preserved in $4 \%$ formalin. Specimens were subsequently identified in the laboratory using taxonomic keys for hermit crabs $[5,6]$ and gastropods (7) and bivalves [8] Abundance was scored as rare, if only one specimen was collected; common if two or three was collected; and very common, if more than four specimens were collected. 


\section{RESULTS AND DISCUSSION}

The upper shore, which was beyond the reach of high tides, was only colonized by ghost crab, Ocypode ceratophthalma (Plate 1). Ghost crabs live in burrows that reach the water table. There were a few burrows below the Casuarina trees, but the majority was in the upper shore down to about 30 metres from the grass edge. Though the ghost crabs lived on the high shore, they foraged for food near the water's edge. This feeding activity was most obvious during the night. Ghost crabs have been reported to predate on turtle hatchlings migrating to the sea after emerging from their nests on shore.

Other than the ghost crab, there were no visible fauna (except occasional insects) on the sand surface for about 30 metres down from the grass edge. Thus this area was not dug for fauna as the sand surface was dry and devoid of moist. Further down the shore, there were invertebrates (Table 1).

Near the water's edge there was an abundance of invertebrates such as gastropods and sand dollars. The most abundant animal was the sand dollar Arachnoides placenta (Plate 2). The main reason for the aggregation of invertebrates at the water's edge is the abundance of food and moist substrate.

As typical of sandy shores on the east coast of peninsular Malaysia, there was relatively lesser number of fauna compared to sheltered shores. The upper shores of sandy beaches are subjected to intense heat during the day and as such no invertebrate could survive in the extreme environment. The exception is the ghost crab, Ocypode ceratophthalma, which lived in deep burrows and became active during the night when it was relatively cooler.

At the mid shore level (50 metres from the grass edge), the common invertebrates were hermit crab, Diogenes avarus and sand bubbler crab, Scopimera proxima. On the lower shore near the water's edge, there was a greater diversity of invertebrates including polychaetes, gastropods, bivalves, crustaceans like mantid shrimp, mole crab and the echinoderm Arachnoides placenta. Another small sand dollar with a diameter of one $\mathrm{cm}$ was also collected. It had two small holes or lunules on one half of its body. It appears to be the young stages of the key-hole sand dollar Echinodiscus truncatus which lived in the sub-tidal region of the shore. One specimen of a mole crab Hippa sp., a typical inhabitant of pristine tropical sandy shore was collected.
Several environmental parameters influence the distribution of macrofauna from high to the low shore on a beach [9]. Important factors include temperature, salinity, content of water, exposure to air (desiccation) and availability of food. Physiological and physical stresses like water movement, desiccation and light may be important in the vertical distribution of fauna $[10,11]$. Invertebrates at the water's edge are adapted to withstand strong waves and moving sediments. Sand dollars bury themselves in the subsurface sand while gastropods have broad feet which enable them to move on unstable sediment. Bivalves are able to burrow rapidly and avoid being washed away by strong waves.

This study is only an initial attempt to investigate the macrofauna of a sandy beach on an open shore on the east coast of peninsular Malaysia. A more intensive and thorough study is essential to examine the whole spectrum of fauna including micro-and meiofauna living on a sandy shore. The $2 \mathrm{~mm}$ sieve used in this study allows the escape of smaller fauna which live in the interstitial spaces of sand grains [12]. Sieves of mesh sizes 0.5 and $0.1 \mathrm{~mm}$ are required to investigate the meiofauna. The sea shore or intertidal zone is an exciting place to begin work for students of ecology or zoology. Within this area there is a variation of environmental parameters and richness of marine life that a student of ecology could devote many months of intense study and come up with interesting results [13].

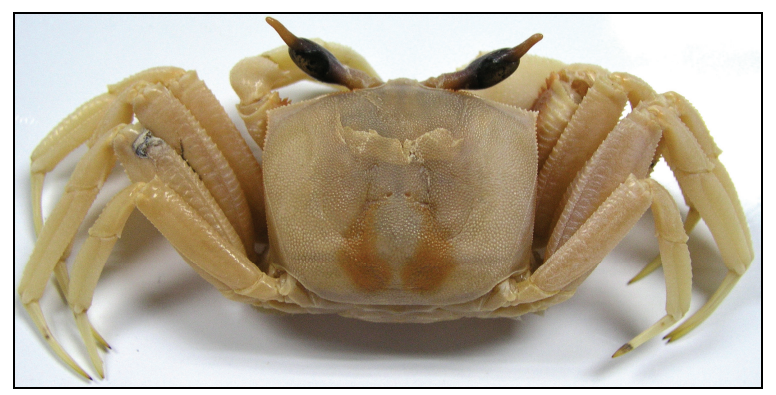

Plate 1. Dorsal view of ghost crab, Ocypode ceratophthalma.

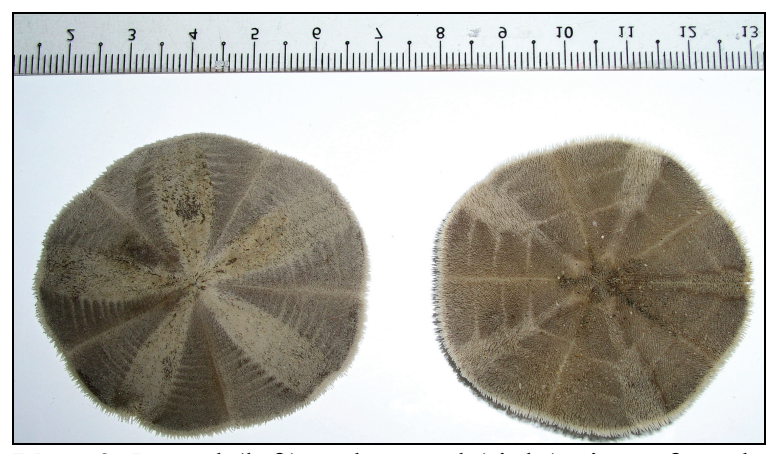

Plate 2. Dorsal (left) and ventral (right) view of sand dollar, Arachnoides placenta. 
Table 1: Fauna of two sandy beaches in Bachok, Kelantan. Invertebrates occurring from high shore to the water's edge near low shore. Distance in metres indicates intervals from grass edge at high shore.

\begin{tabular}{|c|c|c|}
\hline & Sudara Beach Resort & Kuala Rekang (IOES) \\
\hline \multicolumn{3}{|l|}{30 metres } \\
\hline Juvenile Ocypode ceratophthalma & $*$ & $*$ \\
\hline \multicolumn{3}{|l|}{50 metres } \\
\hline Scopimera proxima & $* *$ & $* *$ \\
\hline \multicolumn{3}{|l|}{80 metres } \\
\hline Hermit crab Diogenes avarus & $* *$ & \\
\hline \multicolumn{3}{|l|}{70 metres } \\
\hline Diogenes avarus & $* *$ & \\
\hline Lumbriconereis sp. & & $*$ \\
\hline Nereidae & & $*$ \\
\hline Meretrix sp. & & $*$ \\
\hline Mole crab, Hippa (?) sp. & & $*$ \\
\hline Mantid shrimp & & $*$ \\
\hline Diogenes avarus & & ** \\
\hline Porcellanid crab & & $*$ \\
\hline Calyptraea sp. & & $*$ \\
\hline Arachnoides placenta & & $* * *$ \\
\hline \multicolumn{3}{|l|}{100 metres } \\
\hline Polinices didyna & $*$ & \\
\hline Oliva annulata & $*$ & \\
\hline Terebra sp. & $*$ & \\
\hline Meretrix sp. & $* *$ & \\
\hline Arachnoides placenta & $* * *$ & \\
\hline
\end{tabular}

Abundance: $* * *=$ very common, $* *=$ common and $*=$ rare

\section{ACKNOWLEDGEMENTS}

We gratefully acknowledge financial assistance of PJP research grant FS301/2008A from University of Malaya and IOES for logistical support. Mr. Teoh, H. W. (Lab. B201, IPS) kindly identified the hermit crabs. We appreciate the comments of two anonymous referees.

\section{REFERENCES}

1. Nossin, J.J. (1965). Analysis of younger beach ridge deposits in eastern Malaya. Zeitschnft fur Geomorphologie Band 9:186-208

2. Whitmore, T.C. (1975). Tropical Rain Forests of the Far East. Clarendon Press, Oxford. 282pages.

3. Wong, T M, J K Charles \& T T Khoo (1980). Marine invertebrate resources of the east coast of Peninsular Malaysia. In:Coastal Resources of the east coast of Peninsular Malaysia (eds:Chua T E and J K Charles). Universiti Sains Malaysia, Penang, pp 58-94.
4. Chuang, S.H. (1961) On Malayan Shores. Mumu Shosa, Singapore.

5. McLanghlin, P. A. (2002) A review of the hermit-crab (Decapoda: Anomura:Paguridea) Fauna of Southern Thailand, with particular emphasis on the Andaman Sea, and descriptions of three new species. Phuket Marine Biol Cenre Special Publication 23: 385-460

6. Rahayu, D. L. and Komai T. (2002) Shallow water hermit crabs (Crustaceana: Decapoda: Diogenidae and Paguridae) of Phuket, Thailand. Phuket Mar Biol Centre Res Bull 63: 21-44

7. Poniter, J M (1988a) Gastropods. In: The Living Resources of the Western Central Pacific (Eds: Carpentar K E \& V H Niem). FAO Rome. Pp 364-648

8. Pontier, J.M (1988b) Bivalves. In:The Living Resources of the Western Central Pacific (Eds: Carpenter K E \& V H Niem) FAO, Rome. Pp 124-362

9. Eltringham, S.K. (1971). Life in Mud and Sand. The English Universities Press Ltd. London. 
10. Gray, J. (1981). The Ecology of Marine Sediments. An introduction to the structure and function of benthic communities. Cambridge University Press, London.

11. McLachlan, A. (1983). Sandy beach ecology - a review. In: Sandy beaches as Ecosystems (eds. A. McLachlan \& T. Erasmus). Junk Publishers, The Hague, pp 321-380.

12. Raffaelli, D. and Hawkins, S J. (1996) Intertidal Ecology. Kluwer Academic Publishers, Netherlands.

13. Southward, A. J. (1966) Life on the Sea Shore. Heinemann Educational Books Ltd, London. 